\title{
Chemical composition of plantain foliage (Musa paradisiaca) and the effect of its inclusion in the diet on nutrient digestibility in pig
}

\author{
J. Ly, A. Garcia and P.L. Dominguez
}

Swine Research Institute

P.O. Box 1, Punta Brava

La Habana, Cuba

(Received 22 July 1996; accepted 15 May 1997)

\begin{abstract}
ABSTRAC'
Plantain foliage (PF) meal contained, on dry basis, $626.9 \mathrm{~g} / \mathrm{kg} \mathrm{NDF}, 445.3 \mathrm{~g} / \mathrm{kg} \mathrm{ADF}, 86.5 \mathrm{~g} / \mathrm{kg}$ lignin, $123.0 \mathrm{~g} / \mathrm{kg} \mathrm{N} \times 6.25,148.6 \mathrm{~g} / \mathrm{kg}$ ash, $16.90 \mathrm{MJ} / \mathrm{kg}$ DM gross energy. The effect of feeding PF on nutrient digestibility in the pig was investigated in either ileorectostomized or intact pigs fed graded levels of PF 0,100 and $200 \mathrm{~g} / \mathrm{kg}$ in the dict, respectively). PF significantly decreased ileal and faecal digestibility of most nutrients. The contribution of the large intestine to the digestion of diets ranged from 13.0 to $22.5 \%$ of energy disappearance in the gastrointestinal tract. Estimated ileal and faecal crude protein digestibility of PF meal was 34.7 and $50.8 \%$ whereas in vitro crude protein digestibility of PF meal accounted for $42.0 \%$, thus indicating a rather low availability of crude protein in the biomass. Daily ileal and faecal output of both short chain fatty acids (SCFA) and ammonia showed a trend to be proportional to the level of PF in the diet. It is suggested that PF meal should be used at low levels of inclusion in the pig's diet if a negative effect on nutrient digestibility is to be avoided.
\end{abstract}

KEY WORDS: pigs, plantain foliage meal, digestibility, fermentation

\section{INTRODUCTION}

Although it has long been recognized that feeding of pigs with either banana or plantain foliage (PF) residues is a common practice in the tropics (e.g. Nitis, 1968; Falvey and Visitpanich, 1979), there are very few reports concerning the nutritive value of this type of biomass for pigs as compared to other species such 
as ruminants (Ffoulkes et al., 1978; Hagemeister and Ahrens, 1986) or rabbits (Carew et al., 1989).

On the other hand, PF has been claimed to contain protein levels as high as $14.2 \%$ (Carew et al., 1989) or $16.1 \%$ (Devendra, 1979), but its digestibility has not been well established in non-herbivorous, monogastric animals that are capable of only otherwise constrained to perform a relatively limited utilisation of the protein fraction of crop residues due to the its high proportion of cell wall constituents in the residues (Low, 1985). However, preliminary studies conducted with young pigs indicated that low levels of PF meal in the diet did not impair neither performance traits nor digestibility of nutrients (Garcia and Ly, 1994; 1995).

The aim of the study was to determine the composition of PF and to study the effect of graded levels of PF in the diet on the nutrient digestibility in pigs.

\section{MATERIAL AND METHODS}

\section{Plantain foliage preparation}

The PF was from a variety (Musa paradisiaca) common in Havana province, Cuba, collected during fruit harvesting. The leaves and about one third of the pseudo-stem were ground then sun-dried and milled. The resulting batch of PF meal was used for approximate chemical analysis and in digestion trials on pigs.

\section{Digestion studies}

A basal diet (PFO) consisting of maize and soyabean meal was partially replaced by graded levels of $\mathrm{PF}$ meal in digestion studies with pigs. The composition of the experimental diets and their chemical characteristics are shown in Table 1.

Two separate trials (Experiments 1 and 2) for ileal and faecal digestibility measurements were conducted with YLD castrated male pigs with a mean live weight of approximately $50 \mathrm{~kg}$.

Experiment 1. The ileal digestibility study was conducted on three pigs that were prepared with an end-to-end ileo-rectal anastomosis according to Green et al. (1987). Each pig was randomly assigned to one of the three dietary treatments in a $3 \times 3$ Latin square design. The animals were maintained in adjustable metabolism crates. The temperature of the room was not controlled and was about $28^{\circ} \mathrm{C}$. The average daily feed supply was $0.08 \mathrm{~kg} \mathrm{DM}$ per $\mathrm{kg} \mathrm{W} \mathrm{W}^{0.75}$ and the 
TABLE 1

Composition of the diets

\begin{tabular}{|c|c|c|c|}
\hline \multirow{2}{*}{ Indices } & \multicolumn{3}{|c|}{ Diets } \\
\hline & PF0 & PF10 & PF20 \\
\hline \multicolumn{4}{|l|}{ Ingredients, $\mathrm{g} / \mathrm{kg}$} \\
\hline maize meal & 747 & 670 & 596 \\
\hline soyabean oilmeal & 223 & 201 & 178 \\
\hline plantain foliage meal & - & 100 & 200 \\
\hline $\mathrm{CaHPO}_{4} \cdot 2 \mathrm{H}_{2} \mathrm{O}$ & 10 & 10 & 10 \\
\hline $\mathrm{CaCO}_{3}$ & 5 & 5 & 4 \\
\hline $\mathrm{NaCl}$ & 5 & 5 & 4 \\
\hline vitamins and trace clements & 10 & 9 & 8 \\
\hline \multicolumn{4}{|l|}{ Chemical composition, $\mathrm{g} / \mathrm{kg}$} \\
\hline $\begin{array}{l}\text { Dry matter } \\
\text { In dry matter: }\end{array}$ & 921.5 & 923.3 & 925.0 \\
\hline ash & 34.3 & 45.8 & 57.1 \\
\hline organic matter & 965.7 & 954.2 & 942.9 \\
\hline crude protein & 165.6 & 161.3 & 156.3 \\
\hline crude fibre & 37.1 & 69.3 & 101.5 \\
\hline NDF & 114.9 & 166.9 & 217.3 \\
\hline Gross encrgy, MJ/kg DM & 18.0 & 17.9 & 17.8 \\
\hline
\end{tabular}

1 supplied per $\mathrm{kg}$ diet: $27 \mathrm{mg} \mathrm{FeSO}{ }_{4} \cdot 7 \mathrm{H}_{2} \mathrm{O}, 10 \mathrm{mg} \mathrm{MnSO}_{4} \cdot 4 \mathrm{H}_{2} \mathrm{O}, 15 \mathrm{mg} \mathrm{CuSO} \cdot \cdot 5 \mathrm{H}_{2} \mathrm{O}$, $85 \mathrm{mg} \mathrm{MgSO}_{4} \cdot 7 \mathrm{H}_{2} \mathrm{O}, 0.3 \mathrm{mg} \mathrm{CoSO} \cdot 7 \mathrm{H}_{2} \mathrm{O}, 0.1 \mathrm{mg} \mathrm{KI}, 0.02 \mathrm{mg} \mathrm{Na}_{2} \mathrm{SeO}_{3}, 1600$ I.U. vitamin $\mathrm{A}$, 300 I.U. vitamin $D_{3}, 2 \mathrm{mg}$ thiaminc, $3 \mathrm{mg}$ riboflavine, $300 \mathrm{mg}$ cholinc, $15 \mathrm{mg}$ niacin, $5 \mathrm{mg}$ panthotenic acid, $15 \mathrm{mg}$ pyridoxine, $0.5 \mathrm{mg}$ folic acid, $25 \mathrm{mg}$ cyanocobalamine

animals were weighed weekly for the purpose of adjusting feed allowance. The diets were offered twice daily at two equal meals at 9:00 and 15:00 h. Drinking water was given ad libitum.

Continuous collection of digesta for 2 consecutive days was preceded by 5 days of adaptation to the experimental diet. The procedure for collection of digesta and samples preparation was described by Ly et al. (1995).

Experiment 2. Faecal digestibility measurements were performed by the indirect indicator method (AIA), on six intact pigs which were allocated to the treatments according to a double $3 \times 3$ Latin square design. After a 7 day adaptation period in individual pens, a grab samples were taken. The level of feeding was adjusted to the initial live weight and was maintained constant during each sampling period. The level of feed intake was as described in Experiment 1.

In addition to the in vivo digestibility studies, the in vitro crude protein digestibility of PF meal was assayed by the technique of Dierick et al. (1985) 


\section{Chemical analyses}

Chemical composition of feeds and facces was determined according to AOAC methods (1990) and gross energy in an adiabatic bomb calorimeter. Composition of cell wall constituents was estimated as outlined by Van Soest and Wine (1967). Lignin was measured by $72 \%$ sulphuric acid digestion of acid detergent fibre (ADF) according to van Soest (1963), and detergent tannins according to Conklin et al. (1987) methods.

All amino acids, except tryptophan and sulphur amino acids, were determined in defatted samples after acid hydrolysis by the standard technique as described by Coto et al. (1981) on Carlo Erba automatic amino acid analyser.

Ileal samples were thoroughly mixed and a fresh aliquot was used to determine $\mathrm{N}$ (AOAC,1990), pH by a glass electrode, and fermentation indices. Total short chain fatty acids (SCFA) were estimated by titration after steam distillation according to Ly (1986), and ammonia was determined by microdifusion analysis (Conway, 1962). Another sample of ileal material was oven dried $(\mathrm{C})$ and ground to pass a $1 \mathrm{~mm}$ sieve.

Acid insoluble ash was estimated according to the method of Van Keulen and Young (1977).

\section{Statistical analyses}

The differences between digestibility values were examined by analysis of variance (Steel and Torrie, 1980), with means compared by Duncan's new multiple range test.

\section{RESULTS AND DISCUSSION}

\section{Chemical composition of plantain foliage meal}

The results shown in Table 2 indicate that PF meal was characterized by a its high cell wall content. Cellulose (ADF - detergent lignin) was the main cell wall constituent and the cellulose: hemicllulose ratio was approximately 2 . In contrast, Garcia et al. (1973) and Pezo and Fanola (1980) found a cellulose : hemicellulose ratio of 1 for both banana leaves and stalks, respectively. This discrepancy is difficult to explain, although differences in the examined species of Musa could partially account for it. On the other hand, detergent tannins accounted for $83.7 \mathrm{~g} / \mathrm{kg} \mathrm{DM}$, a value equivalent to that of detergent lignin.

An important characteristic of the PF meal was its that of the relatively low level of crude protein $(123.0 \mathrm{~g} / \mathrm{kg}$ ). However, more than $60 \%$ of nitrogen was 
TABLE 2

Composition of plantain foliage meal, $\mathrm{g} / \mathrm{kg} \mathrm{DM}$

\begin{tabular}{lr}
\hline Dry matter & 939.2 \\
In dry matter; & \\
ash & 148.6 \\
crude protein (N x 6.25) & 123.0 \\
ether extract & 64.0 \\
crude fibre & 359.4 \\
N-frec cxtractives & 304.8 \\
NDF & 626.9 \\
$\Lambda$ DF & 445.3 \\
cellulose & 358.8 \\
detergent lignin & 86.5 \\
detcrgent tannins & 83.7 \\
Gross energy, MJ/kg DM & 16.9 \\
\hline
\end{tabular}

TABLE 3

Amino acid composition of plantain foliage meal

\begin{tabular}{lcc}
\hline & $\mathrm{g} / \mathrm{kg} \mathrm{DM}$ & $\mathrm{g} / 16 \mathrm{~g} \mathrm{~N}$ \\
\hline Amino acids: & & \\
aspartic acid & 6.60 & 6.08 \\
threonine & 2.87 & 2.64 \\
serine & 2.87 & 2.64 \\
glutamic acid & 8.41 & 7.74 \\
proline & 2.66 & 2.45 \\
glycine & 4.90 & 4.51 \\
alanine & 4.26 & 3.92 \\
valine & 4.47 & 4.12 \\
isoleucine & 3.51 & 3.23 \\
leucine & 5.43 & 5.00 \\
tyrosine & 6.50 & 5.99 \\
phenylalanine & 2.70 & 2.49 \\
histidine & 1.34 & 1.23 \\
lysine & 2.34 & 2.16 \\
arginine & 2.13 & 1.96 \\
\hline
\end{tabular}

' cystine, methionine and tryptophan were not determined

present in the form of amino acids. The amino acid composition of PF meal is shown in Table 3.

Ileal and faecal digestibility of plantain foliage meal

A low level of feed intake such as that used in the present study did not allow feed refusals in any circumstance, in spite of the bulking properties of the diets. 
TABLE 4

Ileal and faccal flow of digesta and water

\begin{tabular}{|c|c|c|c|c|}
\hline \multirow{2}{*}{ Indices } & \multicolumn{3}{|c|}{ Diets } & \multirow[b]{2}{*}{ SE } \\
\hline & PF0 & PF10 & PF20 & \\
\hline \multicolumn{5}{|l|}{ Experiment 1} \\
\hline \multicolumn{5}{|c|}{ Ileal flow, g/day per $\mathrm{kg}$ DM intake } \\
\hline fresh digesta & $2136^{x}$ & $2623^{\mathrm{h}}$ & $2940^{\mathrm{b}}$ & $237^{*}$ \\
\hline water & $1882^{\mathrm{a}}$ & $2322^{\text {ab }}$ & $2616^{\mathrm{b}}$ & $210^{*}$ \\
\hline Ileal DM, \% & $11.92^{\mathrm{a}}$ & $11.47^{\mathrm{ab}}$ & $11.00^{\mathrm{b}}$ & $0.10^{*}$ \\
\hline \multicolumn{5}{|l|}{ Experiment 2} \\
\hline \multicolumn{5}{|c|}{ Faecal flow, g/day per $\mathrm{kg} \mathrm{DM}$ intake } \\
\hline water & $217^{\mathrm{a}}$ & $364^{2 b}$ & $713^{b}$ & $103^{*}$ \\
\hline Faccal DM, \% & 31.93 & 27.36 & 28.26 & $0.92^{+}$ \\
\hline
\end{tabular}

${ }^{\perp} \mathrm{P}<0.10$

$* \mathbf{P}<0.05$

a. $b<0.05$

On the other hand, post-mortem examination of gastrointestinal tract showed no abnormalities in the ileorectostomized pigs.

A significant effect $(P<0.05)$ of the diet was found on daily ileal and faecal fresh output and water flow (Table 4). On the other hand, the introduction of graded levels of PF meal appeared to be associated with a decrease in DM concentration in both sites of measurements. These results are in accordance with other observations where ileal and faecal flow of either fresh material or water were associated with an increase in the proportion of cell wall constituents in the diet (Sandoval et al.,1987; Cherbut et al.,1988; Longland and Low,1989).

Substitution of the basal diet with an increasing proportion of PF meal resulted in a reduction of both ileal and faecal digestibility of nutrients (Table 5). This effect achieved a higher significance $(\mathbf{P}<0.01)$ on ileal crude fibre and NDF digestibility. However, ileal ash and energy digestibility appeared not to be influenced by the type of diet given to the pigs. Ileal digestibility of some fractions of fibre has been documented after fecding a variety of diets (Vervaeke et al., 1991; Shi and Noblet, 1993). In this connection Graham (1988) has suggested that some dietary fibres can be degraded in the small intestine thus facilitating a more complete pre-caecal digestion of other nutrients. Faecal digestibility of most nutricnts and energy in the diet with the highest level of PF was significantly different $(\mathrm{P}<0.05)$ from the basal diet $(\mathrm{PFO})$.

The contribution of the large intestine to the digestion of diets ranged from 13.0 to $22.5 \%$ of energy disappearance in the gastrointestinal tract. These data 
Ilcal and faccal digestibility of nutrients and energy, $\%$

\begin{tabular}{|c|c|c|c|c|}
\hline \multirow{2}{*}{ Indices } & \multicolumn{3}{|c|}{ Diets } & \multirow[b]{2}{*}{ SE } \\
\hline & $\mathrm{PF} 0$ & PF 10 & PF20 & \\
\hline \multicolumn{5}{|l|}{ Ileal digcstibility } \\
\hline dry matter & $74.5^{\mathrm{a}}$ & $69.9^{\mathrm{ab}}$ & $67.6^{b}$ & $1.1^{*}$ \\
\hline ash & 38.4 & 39.5 & 44.0 & 1.4 \\
\hline organic matter & $77.5^{\mathrm{a}}$ & $73.0^{\mathrm{ab}}$ & $70.2^{\mathrm{b}}$ & $1.1^{*}$ \\
\hline nitrogen & $69.2^{\mathrm{a}}$ & $67.3^{\text {ab }}$ & $60.7^{\circ}$ & $1.8^{*}$ \\
\hline crude fibre & $21.5^{\mathrm{a}}$ & $11.3^{b}$ & 5.0 & $8^{* *}$ \\
\hline NDF & $45.6^{\mathrm{a}}$ & $33.5^{\mathrm{b}}$ & 22.2 & $9^{* *}$ \\
\hline energy & 73.7 & 69.5 & 68.8 & 1.4 \\
\hline \multicolumn{5}{|l|}{ Faecal digestibility } \\
\hline dry matter & $90.8^{a}$ & $87.9^{\prime \prime}$ & $78.2^{\mathrm{b}}$ & $1.2^{*}$ \\
\hline ash & $58.8^{\mathrm{a}}$ & $64.0^{\mathrm{a}}$ & $47.4^{\mathrm{b}}$ & $1.3^{*}$ \\
\hline organic matter & $91.9^{\circ}$ & $89.1^{: 1}$ & $80.1^{\mathrm{b}}$ & $1.2^{*}$ \\
\hline nitrogen & $86.6^{\circ}$ & $83.2^{\mathrm{ab}}$ & $80.8^{b}$ & $1.8^{*}$ \\
\hline crude fibre & $72.4^{a}$ & $66.5^{\text {ab }}$ & $49.1^{\mathrm{b}}$ & $3.7^{*}$ \\
\hline NDF & $75.4^{4}$ & $66.7^{\mathrm{ab}}$ & $58.8^{\mathrm{h}}$ & $2.5^{*}$ \\
\hline energy & $91.3^{\mathrm{a}}$ & $89.7^{a}$ & $79.1^{\mathrm{b}}$ & 1.4 \\
\hline
\end{tabular}

* $\mathrm{P}<0.05 ;{ }^{* *} \mathrm{P}<0.01$

a. b. c $<0.05$

are in accordance with those of Shi and Noblet (1993) who reported that the large intestine contributed 16 and $25 \%$ of total DE in growing pigs and sows, respectively. A similar range was obtained for $\mathrm{N}$ digested in the large intestine (19.1-24.8\%, respectively). On the other hand, in agreement with other previous studies (Chesson et al., 1985; Shi and Noblet, 1993) the present experiments showed that a large proportion of different fibre fractions was extensively digested in the caecum and colon. Since cellulose is generally considered to be the predominant cell wall constituent in crude fibre, then it could be assumed that cellulose degradation in the large intestine was substantial.

In vitro crude protein digestibility revealed a rather low value for PF meal (Table 6). Ileal and faecal crude protein digestibility estimated by difference were low too ( 34.7 and $50.8 \%$, respectively). Low crude protein digestibility estimated in vitro has been reported also in grass meal (Dierick et al.,1985). Therefore, it is very probable that a great proportion of protein is linked to the fibre fraction of the foliage of plantains, and due to it enzymatic breakdown of those polypeptides must be inhibited.

A significant increase $(P<0.05)$ in ileal SCFA concentration with the increase of PF meal in the diet was observed (Table 7). A similar trend was found in faecal 
TABLE 6

Contribution of the large intestine in digestion of diets

\begin{tabular}{lrrr}
\hline \multirow{2}{*}{ Indices } & \multicolumn{3}{l}{ Diets } \\
\cline { 2 - 4 } & PF0 & PF10 & PF20 \\
\hline Digestibility, \% & & & \\
dry matter & 16.3 & 18.0 & 10.6 \\
ash & 20.4 & 24.5 & 3.4 \\
organic matter & 14.4 & 16.1 & 9.9 \\
nitrogen & 17.4 & 15.9 & 20.1 \\
crude fibre & 50.9 & 55.2 & 44.1 \\
NDF & 29.8 & 33.2 & 36.6 \\
energy & 17.6 & 20.2 & 10.3 \\
& & & \\
Contribution to overall digcstion, \% & & & 13.6 \\
dry matter & 18.0 & 20.5 & 7.2 \\
ash & 34.7 & 38.3 & 12.4 \\
organic matter & 15.7 & 18.1 & 24.8 \\
nitrogen & 20.1 & 19.1 & 89.8 \\
crudc fibre & 70.3 & 83.0 & 62.2 \\
NDF & 39.5 & 49.8 & 13.0 \\
energy & 19.3 & 22.5 & \\
\hline
\end{tabular}

TABLE 7

In vivo and in vitro crude protein digestibility, $\%$

\begin{tabular}{lcc}
\hline & Casein & PF meal \\
\hline In vivo digestibility & & \\
$\quad$ ileal & - & $34.7 \pm 3.2$ \\
$\quad$ faccal & - & $50.8 \pm 9.4$ \\
In vitro digestibility & $96.4 \pm 1.11$ & $42.0 \pm 8.7$ \\
\hline
\end{tabular}

' calculated by difference (see text)

SCFA concentration $(\mathrm{P}<0.10)$. In contrast, $\mathrm{NH}_{3}$ concentration in both ileal digesta and faeces appeared not to be influenced by the diet. On the other hand, the $\mathrm{pH}$ showed a trendency to decrease $(\mathrm{P}<0.10)$ in the content of the ileum or to increase $(\mathrm{P}<0.05)$ in faeces. Daily faecal flow of end-products of fermentative activity showed a significant augmentation $(\mathrm{P}<0.01)$ with the increased introduction of graded levels of PF meal in the diet. This same effect was weaker $(\mathrm{P}<0.10)$ for daily ileal flow of SCFA. In this connection, a highly significant $(\mathbf{P}<0.001)$ interdependence between daily flow of SCFA and organic matter digestibility was noted in both sites of measurements and were in agreement with previous observations made by Jentsch et al. (1990) and Ly et al. (1995). 
TABLE 8

Ileal and faecal indices of fermentation in pigs

\begin{tabular}{|c|c|c|c|c|}
\hline \multirow{2}{*}{ Indices } & \multicolumn{3}{|c|}{ Diets } & \multirow[b]{2}{*}{ SE } \\
\hline & PF0 & PFIO & PF20 & \\
\hline \multicolumn{5}{|c|}{ Experiment 1} \\
\hline \multicolumn{5}{|c|}{ Ileal concentration, $\mathrm{mmol} / 100 \mathrm{~g} \mathrm{DM}$} \\
\hline SCFA & $53.24^{\mathrm{a}}$ & $88.87^{b}$ & 101.25 & $8.21^{*}$ \\
\hline $\mathrm{NH}_{3}$ & 9.98 & 7.28 & 10.94 & 2.10 \\
\hline Ileal pH & 6.60 & 6.47 & 6.20 & $0.15^{\prime}$ \\
\hline \multicolumn{5}{|c|}{ Daily ileal frow, $\mathrm{mmol} / \mathrm{kg} \mathrm{DM}$ intake } \\
\hline SCFA & 194.37 & 410.99 & 662.22 & $218.35^{+}$ \\
\hline $\mathrm{NH}_{3}$ & 25.36 & 22.13 & 34.86 & 3.47 \\
\hline \multicolumn{5}{|c|}{ Experiment 2} \\
\hline \multicolumn{5}{|c|}{ Faecal concentration, $\mathrm{mmol} / 100 \mathrm{~g} \mathrm{DM}$} \\
\hline SCFA & 55.45 & 68.71 & 67.95 & 15.20 \\
\hline $\mathrm{NH}_{3}$ & 15.43 & 19.26 & 17.00 & 0.89 \\
\hline Faecal pH & $5.76^{\mathrm{a}}$ & $5.86^{\mathrm{ab}}$ & $6.06^{b}$ & $0.05 *$ \\
\hline \multicolumn{5}{|c|}{ Daily faecal flow, mmol $/ \mathrm{kg}$ DM intake } \\
\hline SCFA & $6.32^{\mathrm{a}}$ & $93.38^{\mathrm{b}}$ & 189.12 & $5.54^{* *}$ \\
\hline $\mathrm{NH}_{3}$ & 14.26 & $23.16^{\mathrm{b}}$ & 36.96 & $1.60^{* *}$ \\
\hline
\end{tabular}

$+\mathrm{P}<0.10 ;{ }^{*} \mathrm{P}<0.05 ;{ }^{* *} \mathrm{P}<0.01$

a, b. $c-P<0.05$

\section{CONCLUSIONS}

It can be concluded from the results of this study that both ileal and faecal digestibility of nutrients in the pig is reduced with increasing amounts of a tropical fibre source such as a foliage of plantain in the diet. Thus, a greater understanding of the physiological influences of fibre requires more information on the chemical composition of the cell wall of this feed. Moreover, methods to improve either crude protein or fibre digestibility in the pig would be of great utility in this type of biomass that is of great availability in the tropical environment. 


\section{REFERENCES}

A.O. A.C., 1990. Official Methods of Analysis. 15th ed. Association of Official Analytical Chemists. Washington, D.C.

Carew S.N., Ayodade J.A., Zungwe E.N., 1989. Composition of plants fed to rabbits in Benin State of Nigeria. J. Appl. Rabbit Res.12, 169-170

Cherbut C., Barry J.L., Wyers M., Delort-Laval J., 1988. Effect of the nature of dictary fibre on transit time and faecal excretion in the growing pig. Anim. Feed Sci. Technol. 20, 327-333

Chesson A., Richardson A.J., Robertson J.A., 1985. Fibre digestion and bacteriology of the digestive tract of pigs fed cereals and vegetable fibre. In: A. Just, H. Jorgensen, J.A. Fernandez (Editors). Digestive physiology in the pig. Beret. Stat. Husdyrbrugsfors. Kobenhavn., pp. 272-275

Conklin N.L., Horvarth P.J., Van Soest P.J., McDowell R.E., 1987. Predicting the digestibility of tropical browses. J. Anim. Sci. 65, Suppl.1, 339

Conway E.J., 1962. Microdiffusion Analysis and Volumetric Error. Crosby, Lockwood and Sons Ltd., London

Coto G., Geerken C.M., Cruz, R., 1981. Levels of amino acids in the duodenum of lactating cows fed coast cross bermuda grass (Cynodon dactylon) forage. Passage of nitrogenous fractions. Cuban J. Agric. Sci.15, 85-93

Devendra C., 1979. Malaysian Fecdingstuffs. Malaysian Agric. Res. Devel. Inst. Scrdang, pp. 145

Dicrick N., Vervaeke I., Decuypere J., Henderickx H.K., 1985. Protein digestion in pigs measured in vivo and in vitro. In: A. Just, II. Jorgensen, J.A. Fernandez. (Editors). Digestive physiology in pig. 580 Beret Stat. Husdyrbrugsfors Kobenhavn., pp. 329-332

Falvey L., Visitpanich T., 1979. Nutrition of highland swine. 2. Preparation of pigeon pea seed fed in conjunction with rice bran and banana stalk. Thai J. Agric. Sci.13, 29-34

Foulkes D., Espcjo S., Maric D., Delpeche M., Preston T.R., 1978. EI plátano en la alimentación de bovinos: composición y producción de biomasa. Prod. Anim. Trop. 3, 41-46

García C.E., Chicco C.F., Carnavali A., 1973. Una nota sobre el uso de la harina de hoja de plátano en la alimentación de rumiantes. Agron. Trop. 23, 293-299

García A., Ly J., 1994. Uso de diferentes niveles de residuos foliares del plátano en la alimentación del cerdo. Comportamiento de cerdos en ceba. Rev. Comp. Prod. Porcina. 1(1), 61-66

Garcia A., Ly J., 1995. Lso de diferentes niveles de residuos foliares del plátano (Musa spp) en la alimentación del cerdo. Digestibilidad del cerdo en preceba. Rev. Comp. Prod. Porcina. 2(1), $68-75$

Graham H., 1988. Dietary fibre concentration and assimilation in swinc. Anim. Plant Sci.1, 76-80

Green S., Bertand S.L., Duron M.J.C., Maillard R.A., 1987. Digestibility of amino acids in maize, wheat and barley meal, measured in pigs with ileo-rectal anastomosis and isolation of the large intestine. J. Sci. Food $\Lambda$ gric. 41, 29-43

Hagemeister H., Ahrens F., 1986. Verdaulichkeit und Futteraufnahme von Bagasse, verschiedenen Stroharten und Ananas-sowic Bananenblättern nach Dampfdruckbehandlung beim Wiederkäuer. J. Anim. Physiol. Anim. Nutr. 55, 134-143

Jentsch W., Hennig U., Wunsche J., Wittenberg H., Souffrant W.B., 1990. Methodological studies on the formation of $\mathrm{CO}_{2}$ and volatile fatty acids in porcine ileo-chyme and faeces. Arch. $\Lambda \mathrm{nim}$. Nutr. 40, 1019-1026

Longland A.C., Low A.G., 1989. Digestion of dicts containing molasses or plain sugar-beet pulp by growing pigs. Anim. Feed Sci. Technol. 23, 67-78

Low A.G., 1985. Role of dietary fibre in pig diets. In: W. Haresign, D.E. Cole (Editors). Recent advances in animal nutrition. Butterworths, London, pp. 87-112

Ly J., 1986. Large intestine digcstion of pigs fed molasses. 5. VFA production. Cuban J. Agric. Sci. $20,41-49$ 
Ly J., Macas M., Reyes J.L., Figueroa V., 1995. Ileal and faecal digestibility of Jerusalem artichokes (Helianthus tuberosus L.) in pigs. J. Anim. Feed Sci. 4, 195-205

Nitis I.M., 1968. Sweet potato versus banana stem for pig raising. Res. J. Indonesia 28, 8-15

Pezo D., Fanola $\Lambda ., 1980$. Composición química y digestibilidad in vitro del scudotallo y hojas de banana y plátano. Prod. Anim.Trop. 5, 86-89

Sandoval R.A., Niclsen T.K., Sørensen P.H., 1987. Effects of fibre on nutrient digestion and time of passage in growing pigs. Acta Agric. Scand. 37, 367-373

Shi X. S., Noblet J., 1993. Contribution of the hindgut to digestion of diets in growing pigs and adult sows: effect of diet composition. Livest. Prod. Sci. 34, 237-252

Steel R.G.D., Torrie J.H., 1980. Principles and Procedures of Statistics. 2nd ed., McGraw-Hill Book Co., New York

Van Keulen J., Young S.A., 1977. Evaluation of acid insoluble ash as a natural marker in ruminant digestibility studies. J. Anim. Sci. 44, 262-266

Van Soest P.J., 1963. Use of detergents in the analysis of fibrous feeds. II. A rapid method for the determination of fibre and lignin. J. $\Lambda$ ssoc. Off. Agric. Chem. 46, 829-832

Van Soest P.J., Winc R.H., 1967. Usc of detergents in the analysis of fibrous feeds. IV. Determination of plant cell wall constituents. J. Assoc. Off. Agric. Chem, 50, 50-54

Vervaeke I.J., Graham H., Dierick N., Demeyer D.I., Decuypere J.A., 1991. Chemical analysis of cell wall and energy digestibility in growing pigs. Anim. Feed Sci. Technol. 32, 55-61

\section{STRESZCZENIE}

\section{Sklad chemiczny liści i lodyg bananowca (PF) i wpływ mączki PF na strawność składników pokarmowych dicty u świń}

Skład suchej masy PF jest następujący (g/kg): białko ogólne 123,0; popiół 148,6; NDF 626,9; ADF 445,3; lignina 86,5 , oraz $16,9 \mathrm{MJ}$ energii brutto/kg. Udział $P F$ w dawkach dla świń z przetokami i nieprzetokowanych wynosil 0,100 i $200 \mathrm{~g} / \mathrm{kg}$. Dodatek PF istotnic obniżyl strawność większości składników pokarmowych. Udział procesów trawiennych w jelicie grubym w stosunku do strawności w calym przewodzie pokarmowym wyrażony ubytkiem energii wynosił 13,0 do $22,5 \%$. Strawność białka PF oznaczona do końca jelita cienkiego $i$ do końca przewodu pokarmowego wynosiła 34,7 i $50,8 \%$ odpowiednio, podczas gdy oznaczona in vitro $42,0 \%$. Drienne wydzielanie krótkołańcuchowych kwasów tłuszczowych i amoniaku w jelicie cienkim i kale bylo proporcjonalne do udziału $\mathrm{PF} w$ diecie.

Wyniki wskazują, że mączka PF może być stosowana w małych ilościach w żywicniu świń, jeżeli da się uniknąć ujemnego jej wpływu na strawność składników pokarmowych. 